\title{
The Quality Costs Assessment in the Aspect of Value Added Chain
}

DOI: 10.12776/QIP.V20I2.746

\author{
Asta Daunoriene, Egle Staniskiene
}

Received 04 June 2016, Revised 16 July, Accepted 08 October 2016

\begin{abstract}
Purpose: The main purpose of this paper is to focus on the quality costs influence direction and intensity on the added value in the aspect of value chain.

Methodology/Approach: The article is based on a nomothetic point of view that includes three modules: conceptual, hypothetical - deductive and inductive methods. To formulate theoretical aspects of quality costs evaluation, comparative and chronological analysis of scientific literature is used. Empirical results of the research are obtained by applying method of expert evaluation.
\end{abstract}

Findings: During expert evaluation procedure is identified and selected significant quality costs elements. It is a useful tool to identify quality costs thought value chain processes. Created model of quality costs assessment in the aspect of value added chain is based on identification and classification of quality costs elements and allows to measure and to evaluate influence of quality costs, its direction and intensity on the added value.

Research Limitation/implication: The formulated model of quality costs assessment in the aspect of value added chain is assigned to the models that "are oriented towards the situation", i.e. diverted towards organizational analyses.

Originality/Value of paper: The paper complements the gap between theoretical and practical framework of determining influence of quality costs on added value and proves importance of the assessment of quality costs elements in the aspect of added value chain.

Category: Research paper.

Keywords: Quality costs; added value chain; Added value; manufacturing industry. 


\section{INTRODUCTION}

For many years scientists and practitioners have identified quality as a strategic element that generates added value. Moreover, scientists acknowledge that the added value that is generated during the activity of quality improvement is recognized as a tool which helps to regulate market share, to coordinate and to satisfy the needs of stakeholders and to receive economic benefit. Direct organization investments towards quality improvement activities determines the need to monitor and analyse the results of improvement activity and to make new, economically reasonable decisions. According to Campanella (1999) and Wood (2013) the assessment of the investment directed towards quality and the loss associated with quality can be made through application of the analysis of quality cost.

Atkinson (1999) argued that quality costs show the organization a better way towards better quality of activity and financially "healthier activities". Rust, Moorman and Dickson (2002) concluded that quality costs indicate the present level of quality, return on investment and the further trends of quality improvement. The peculiarities of assessment and analysis of quality costs were discussed in the works of quality costs identification through the analysis of the finished product by Bamford and Land (2006), Miguel and Pontel (2004); also by Weheba and Elshennawy (2004), Omachonu, Suthummanon and Einspruch (2004). The peculiarities of assessment and analysis of quality costs in different spheres of industry were carried out by Tye, Halim and Ramayah (2011), Uyar (2008), Tannock and Saelem (2007), Sower, Quarles and Broussard (2007), Ramdeen, Santos and Chatfield, (2007). Other researchers highlighted the importance of quality costs assessment in the applied research area. For example, Ramudhin, Alzaman and Bulgak (2008) performed survey in case of supply chain of quality costs analysis. The conceptual article about the conception of adjustment of quality costs and the applicable methods of accounting was prepared by Fons (2012). The logic of identification of quality costs was presented by Chopra and Garg (2011). The methods of quality costs simulation were summarized by Freeman (2008). The issues of heterogeneity, diversity and complexity of quality costs were reviewed by Emsley (2008).

Despite much research related with the quality costs it needs to be admitted that most of quality costs assessment researches are similar to each other and they state a certain dependency of quality costs alterations on high-quality product or on some individual processes. Researches underestimate the interfaces between quality costs and value creating processes. Such the assessment of quality costs that is often fragmentary becomes inexpedient and it does not provide reasoned information in the decision making process (Eldridge, Balubaid and Barber, 2006). Moreover, according to Reed, Lemak and Mero (2000), Tena, Llusar and Puig (2001), the concept of quality is adjusted by changing environment, which influences changes of quality costs system as well. In accordance with new approach quality is not just usual description of product or service quality. Quality in a broad sense reflects the systematic point to the organization's 
activity quality. According to this approach the system of quality management covers the activities of all organizational processes; which correspond to the part of the added value generating systems (Kaplinsky, 2000, 2004; Kaplinsky and Morris 2001, Barnes, 2002; Christopher, 2005).

The aim of this paper is to address the following research question: what connection is between quality costs and added value? The latter issue is divided into two separate issues: what quality costs influence the value added chain and what is the tendency and intensity of this influence? In order to address this research question, this paper integrates logical and systematic analysis of scientific papers. To set up connections between quality costs and added value the authors develop and test model of quality costs assessment in the aspect of value added chain and conclude with some reflections from the case study.

\section{GENESIS OF QUALITY COSTS CONCEPT}

\section{Quality costs concept}

While the academic literature on quality costs can be traced to the 1950s (Juran, 1951; Feigenbaum, 1951; Lesser, 1954), construction of the quality costs theory related with empirical results is a much more recent development. A considerable amount of quality costs literature has been focused on quality costs implementation rather than searching answers to 'why' issues. It is not probably surprising that scientists and practitioners question the benefit of quality costs.

One of the most problematic issues that need to be mentioned is related with appropriate quality costs definition. According to Machowski and Dale (1998), Wood (2013), there is no common agreement regarding unified and clear description of quality costs; therefore sometimes there is a confusion because of different terms of quality costs. Usually quality costs are understood as the total amount of conformity and unconformity quality costs, when conformity cost are attributed to prevention and assessment quality costs in order to avoid unconformity, and unconformity quality costs are attributed to the internal and external non-conformance quality costs (e.g.: product's return or re-production).

Dale and Plunkett $(1995,1999)$ argue that the quality costs are the costs incurred by the quality management system design, implementation, management and costs related to the continuous improvement, product or service failures and all other costs needed to achieve appropriate level of product or service quality. The issue of Australian Standard (2012, pp.8) provides quality costs definition related with a "costs incurred from failing to provide the required product in the most efficient and effective manner". However, it is important to note that some authors understand quality costs as costs incurred due to non-qualitative product, while other authors describe quality costs as loss related to inefficiency of organizational activity. It is not sufficient to understand quality costs as a set of assessment of loss. This view is supported by Omachonu, Suthummanon and 
Einspruch (2004), who argue that quality costs relate with a possibility to increase product value, process output and customer satisfaction. These findings link quality costs with an added value concept which identifies clear relationships between the organization's activities, products, and processes. Considering aspects of added value, a description of quality costs becomes too narrow concept, i.e. description of quality costs has to integrate the costs related to processes quality and quality costs related to products/service quality. Based on these assumptions quality costs could be described as:

1. added value chain quality costs intended to warranty the implementation of defined characteristics during the resources into the product transformation process; and

2. added value chain failure quality costs related with a non-conformance quality caused problems and effects.

\section{Classification of quality costs}

Classification of quality costs is one of the main tasks in order to identify, account and analyse quality costs. Organization that decided to manage quality costs has to choose proper model of quality costs, which includes categories and elements of quality costs (Omachonu, Suthummanon and Einspruch, 2004; Ramdeen, Santos and Chatfield, 2007, Akkoyun and Ankara, 2009).

Crosby (1979 a, b), Juran and Gryna (1988) developed basics of quality costs classification and assessment by classifying types of quality costs to preventive, appraisal, internal and external failure quality costs. Preventive and assessment costs are ascribed to the group of conformance quality costs, internal and external failure quality costs are ascribed to the group of non - conformance quality costs.

This paper is based on traditional grouping of quality costs to categories of prevention, appraisal, internal failure and external failure quality costs.

The more complex question of how prevention, appraisal, internal failure and external failure quality costs could be described has also been found in a number of scientific papers (Buthmann, 2007; Krishnan, Agus, and Husain, 2000; Kim and Nakhai, 2008; Campanella, 1999; Kaner, 1996). Prevention quality costs are the costs committed for the actions within the purpose to avoid defects and discrepancies and to minimize failure costs and costs related to inspection and testing (Buthmann, 2007; Krishnan, Agus, and Husain, 2000; Kim and Nakhai, 2008; Campanella, 1999; Kaner, 1996). According to Porter and Rayner (1992), in order to define prevention quality costs organizations should evaluate situation (and possible situation) that could influence organization 's results. Prevention quality costs also can be treated as an activity in striving to improve processes and decrease waste. Yang (2008) recommends including into prevention quality costs category: quality planning activities, new products review actions, training, and process development and management activities. 
According to the statement of Cheah, Shahbudin and Taib (2011), prevention quality costs are related to the creation, implementation and support of quality management system. Prevention quality costs are being planned and incurred before execution of different activities. Srivastava (2008) also agrees with this point of view by stating that prevention quality costs are related to the costs of any activity intended to research, warranty and decrease discrepancies.

Sörqvist (1998) indicates that prevention costs are not the costs intended for actions of bad quality correction, it is an investment to activity that warranties certain level of quality. These costs could be evaluated in parallel with costs of loss.

Theoretically, the idea of prevention costs assessment allows organizations to evaluate quality improvement costs in association with the failure costs. Moreover, the obtained results could outline an optimal quality level. However, it is hard to implement such a system from a practical way. Usually in practice organizations can evaluate only a small part of actual quality costs. According to the Sörqvist (1998) segmentation method such quality costs is related to the risk of optimization.

Based on the theoretical analysis results, the authors of the paper describe prevention quality costs as the costs intended for the quality improvement investments in order to prevent defects and discrepancies. As well as to decrease failure quality costs and costs related to inspection and testing (assessment quality costs).

Appraisal quality costs are the costs incurred by assessing the state of products and processes in order to determine if they correspond to the requirements or specifications (Buthmann, 2007; Kim and Nakhai, 2008; Kaner, 1996). According to the Krishnan, Agus and Husain (2000), appraisal costs are being incurred in striving to determine level of correspondence to quality requirements. Srivastava (2008) agrees that appraisal quality costs are the costs intended to assess correspondence to the requirements and their calculations include costs related to the work verification and control process.

In case of every organization appraisal quality costs have to be optimal. Constantly increasing appraisal quality costs can show badly designed processes and constant need for quality improvement actions.

In order to assure the correspondence to establish requirements level appraisal quality costs are related to the assessment of purchased raw materials, outsourced processes, products and services and etc. (Kim and Nakhai, 2008). Moen (1998) states that problem of quality costs assessment is related to the fact organizations do not determine added value. The big amount of appraisal quality costs can indicate the problems related with a product or internal process improvement necessity. 
The above observations call for a comprehensive review of the appraisal quality costs place in the quality costs classification framework (conformance quality costs and non-conformance quality costs).

The appraisal quality costs are costs of routine activity assessment that are based on product or process specifications and that help to warranty the certain quality level of product or process (for example: calibration, inspection, testing and so on), therefore this study keeps latter opinion.

Internal failure quality costs are the costs incurred due to mistakes that indirectly influence customer (Buthmann, 2007; Kiani, et al., 2009; Kim and Nakhai, 2008; Kaner, 1996). In other words, internal failure quality costs are the costs incurred due to mistakes, which are determined inside organization, when products haven't reach customer. Internal failure quality costs cover such elements as surplus of resources, repair of product under manufacturing, downtime, waste and other. Assessment of these costs is complicated; they can include even such elements as investigation of employees' complaints, fines for badly prepared financial reports and so on. Internal failure quality costs occur only in case established quality standards were not reached by work results and that is being determined before transferring the product to customer (Cheah, Shahbudin and Taib, 2011).

Srivastava (2008) states that internal failure quality costs are closely related to discrepancies determined in stages of processes and products quality warranting. Krishnan, Agus and Husain (2000) divide internal failure quality costs into two groups. The first group of internal failure costs includes the costs related to planning work and results of inappropriate decision making, for example, costs related to hiring of employee with inappropriate qualification, dispersion of inappropriate process attitude and etc. The second group of internal failure costs includes costs related to organization routine activity, i.e. everyday activity. These quality costs could be easily identified by process participants. However, the authors of the paper highlight that often in organizations they are being assessed as ,,acceptable norm“.

The authors of the paper describe failure quality costs as the costs that incurred due to mistakes, that are being identified inside organization (in processes, activity, during assessment of product's quality and etc.), when products do not reach customer. In the same way it gives organizations a possibility to assess not only internal failure costs but also to identify places where they occur. Based on such information, organization can take grounded quality improvement decisions by relating them to quality costs intended to preventive or assessment activity.

External failure quality costs are the costs incurred due to mistakes that directly influence customer (Sower, Quarles and Broussard, 2007; Buthmann, 2007; Kiani, et al., 2009; Kim and Nakhai, 2008; Kaner, 1996). In Campanella (1999) and Wood (2013) opinion, external failure quality costs category includes complaints of customers, costs of warranty services, loss of trade mark, costs of decrease of market part and other. In scientific literature external failure quality 
costs often are named as costs of lack of responsibility. In Srivastava's (2008) opinion, external failure quality costs are the costs that appear after transfer of the product to customer, i.e. during use of the product. Most often they could be identified when discrepancies, defects, spoilage and similar defects appear when customers use the product and which became known to organizations because of the customers' claims, activity of warranty services, and costs of product replacement. Krishnan (2006) divides external failure costs into two groups. Into the first group of external failure quality costs the author includes the costs that are related to delivery of the product to customer and period of warranty service. As an example the author presents the costs of warranty service, costs of wrong delivery of product, costs of loss of customers and so on. Into the second group of external failure quality costs the author includes the costs that are related to the costs incurred by customer due to late product delivery and etc., and which are being compensated by organization with penalties. However, in some cases such descriptions of external quality costs related to product's end user do not reflect structure of all external quality costs. Examples presented by Curkovic, Sroufe and Landeros (2008) show that lot of organizations had to pay huge penalties and fines during the last few years due to inappropriate storage and utilization of waste. The authors of the paper state that external failure quality costs should cover not only the costs related to customers but also the quality costs related to other stakeholders that organization's activity makes an impact, management structure and etc.

External failure quality costs are treated as one of the most significant quality costs evaluation of which is the most difficult in comparison to other categories of quality costs (Sower, 2004). This statement is based on the findings that external failure quality costs are being suffered directly by customers and size of these costs in many organizations reaches 50 - 90 percent of total quality costs.

Despite clear enough descriptions and relationships between quality costs categories, the detail elements of quality costs categories' as an operationalized construct is a gap in quality costs literature. Depending on the character of an analysed industry many authors present different elements of quality costs. As reported by Dale and Plunkett (1999) summarized lists of quality costs can be used as guidance or as a source of ideas. Scientists or practitioners should take into account each industry specifics and their quality costs drivers. The major drawback of this approach is the lack of similar quality costs sets which could be used for a benchmarking purpose.

The assessment of quality costs has also been a subject of a number of research. Edward and Sahadev (2011) point out that assessment of quality costs and preparation of reports is the first step towards a program of quality costs management. Information on quality costs can be used to highlight the most important improvement actions and to ground initiation of quality development activities (Edward and Sahadev, 2011; Sharabi and Davidow, 2010). Organizations could expect more valuable benefit only in the case if all quality costs are being assessed. Assessment of quality costs increases possibilities to 
find costs that usually are reflected in organization's additional expenses. Harington (1987), Akkoyun and Ankara (2009) state that, it is important to coordinate the system of quality costs assessment with activities of process development, i.e. to use the results of quality costs analysis for the continuous processes or product improvement. Harington (1987) emphasizes that one of the most important quality costs assessment advantages is that decreasing quality costs tendencies can be the best way to increase organization's profit by improving quality and decreasing the need for additional work resources, raw materials and other elements. Although, quality costs assessment is not only a quality costs management driver; it can also materially affect the reliability of the assessed quality cost (Tawfek, Mohammed and Razek, 2012). A key problem with these arguments is that researches usually provide general view on the assessment of quality costs. The complex relationships between various quality costs elements arise the question of quality costs assessment field and depth. Another big problem related with quality costs assessment is the use of obtained information, which is in many cases related abstractly to the results of improvement activity. This shows that in many cases attention is given to systems and methods of quality costs, but not the results and possibilities for improvement.

As such, the quality costs genesis represents significant problems of quality costs theory construction and testing in the aspect of added value chain. Accordingly, there is need to address the issue of quality costs in measuring added value. In addition, any conceptualization of the quality costs - added value relationship should consider decomposition of organization as sophisticated systems in space of processes, identification of quality costs elements, their grouping into categories of quality costs by performing comparison of their relations to indices reflecting added value.

\section{RESEARCH FRAMEWORK}

Performed analysis of scientific literature content allowed formulation of reasoned assumptions for creation of a research framework of quality costs assessment in the aspect of value added chain. In the first figure, a scheme of logical steps in the creation of a research framework of quality costs assessment in the aspect of value added chain is proposed. 


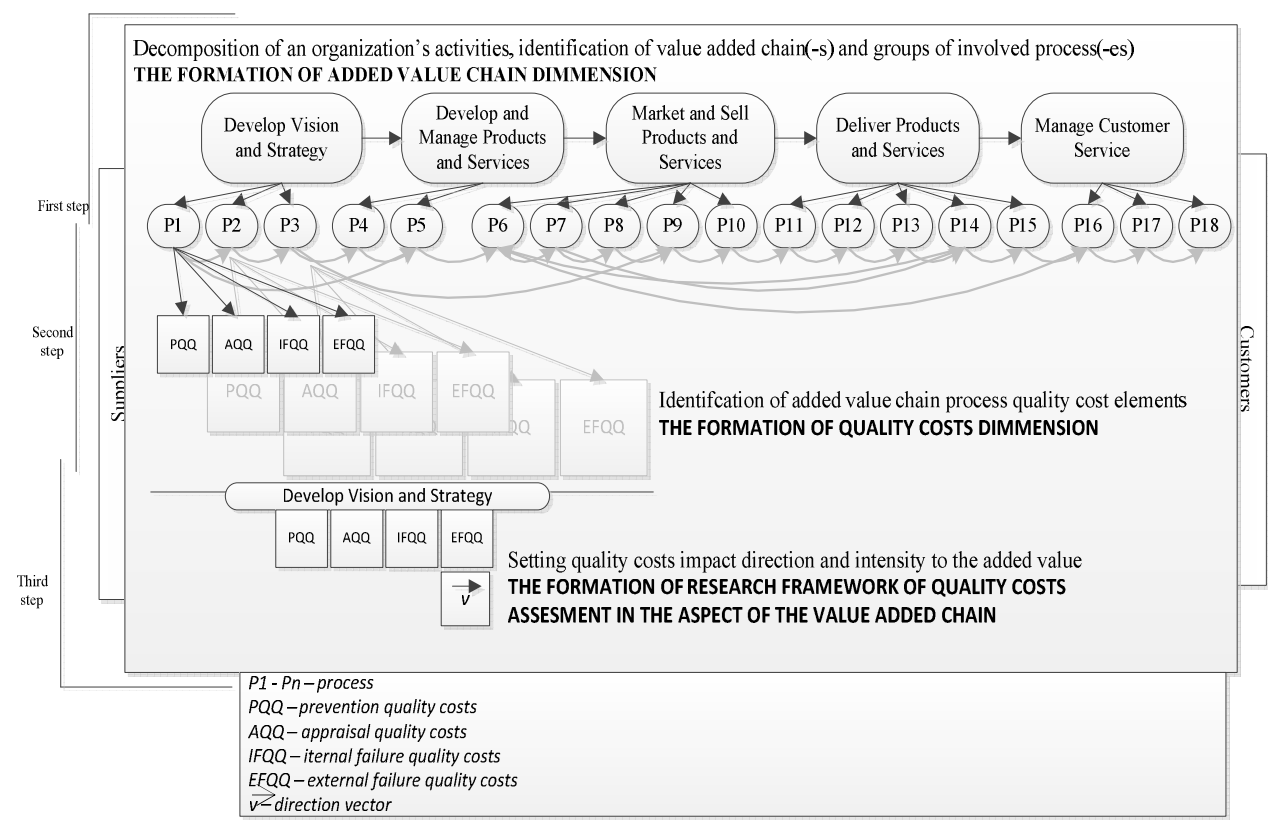

Figure 1 - A scheme of logical steps in the creation of a research framework of quality costs assessment in the aspect of value added chain

First step: the formation of added value chain dimension. According to deductive point of view, by the first step of the research framework of quality costs assessment in the aspect of value added chain, creation obliges to perform decomposition of an organization's activities, identification of value added chain(-s) and groups of involved process(-es). This step is based on Process Classification Framework (APQC, 2012).

Second step: the formation of quality costs dimension. The second step of the research framework of quality costs assessment in the aspect of value added chain from hypothetic-deductive point of view is related to the formation of quality costs dimension in the aspect of added value chain.

The assessment of quality costs in the aspect of added value chain is closely linked with the analysis of process performance. In order to find the most appropriate way to classify quality costs of added value chain, the procedure of this step is based on Multiple Criteria Decision Analysis (MCDA) methodology. Considering principles of Multiple Criteria Decision Analysis principles is formed two directions of quality costs classification system in an aspect of added value chain:

1. Assurance of complex assessment of quality costs.

2. Distinguish of quality costs elements for process quality assessment and continuous improvement decisions (Dale and Wan, 2002). 
Numerous studies have argued that quality costs evaluation methods, concentrate on the certain quality-related activities, which explains the general quality costs, but not all of the interrelated processes activities (Chopra and Garg 2012, Chopra and Garg, 2011; Fons, 2012, Luther and Sartawi, 2011; Ramudhin, Alzaman and Bulgak, 2008, Kim and Nakhai, 2008). The first direction of quality costs classification system in an aspect of added value chain is to fulfil the gap of the existing quality costs research results. Assurance of complex assessment of quality costs facilitates a systematic and complex approach to the assessment of all added value chain quality costs elements. Goulden and Rawlins (1995) argue, that based on the philosophy of continuous improvement, quality cost analysis should show quality cost of each process, rather than the overall product quality costs. Therefore, facing with identified quality cost evaluation problems in order to complete a list of quality costs elements there were analysed a set of scientific papers (Chopra and Garg 2012; Fons 2012, Chopra and Garg, 2011; Abdelsalam, and Gad, 2009; De, 2009; Akkoyun and Ankara, 2009; Jaju, Mohanty and Lakhe, 2009; Srivastava, 2008; Ramudhin, Alzaman and Bulgak, 2008, Yang, 2008; Calegre and Papa, 2007, Eldridge, Balubaid, and Barber, 2006; Bamford and Land, 2006; Weheba and Elshennawy, 2004; Giakatis, Enkawa and Washitani, 2001; Roden and Dale, 2000; Juran and Gofrey, 1998) and standards (Australian Standard AS 2561-1982, 2012). The list of quality costs was used to conduct expert evaluation. The purpose of empirical study was to find out the key quality costs of value added chain processes and to specify quality costs categories relations between the value added chain processes. The research focused on significant well-founded variables. Due to explanatory nature of the analysis was chosen a qualitative research strategy. There was conducted a list of independent experts who were asked to evaluate the importance of added value chai quality costs elements and provide comments. The research data accumulation was based on saturation effect. For the evaluation of importance quality costs elements in the aspect of added value chain there was used 5 points Likert scale. To evaluate scale internal consistency there was calculated Cronbach's alpha coefficient $(\alpha=0,995)$. To test the compatibility of experts' opinion, Kendall's coefficient W was calculated. Based on the accumulative effect of preventive actions (Lorente, Rodriguez and Rawlins, 1998) relationships were tested between quality costs elements in each added value chain process, in each group of value added chain process and in all added value chains (see Figure 2). 


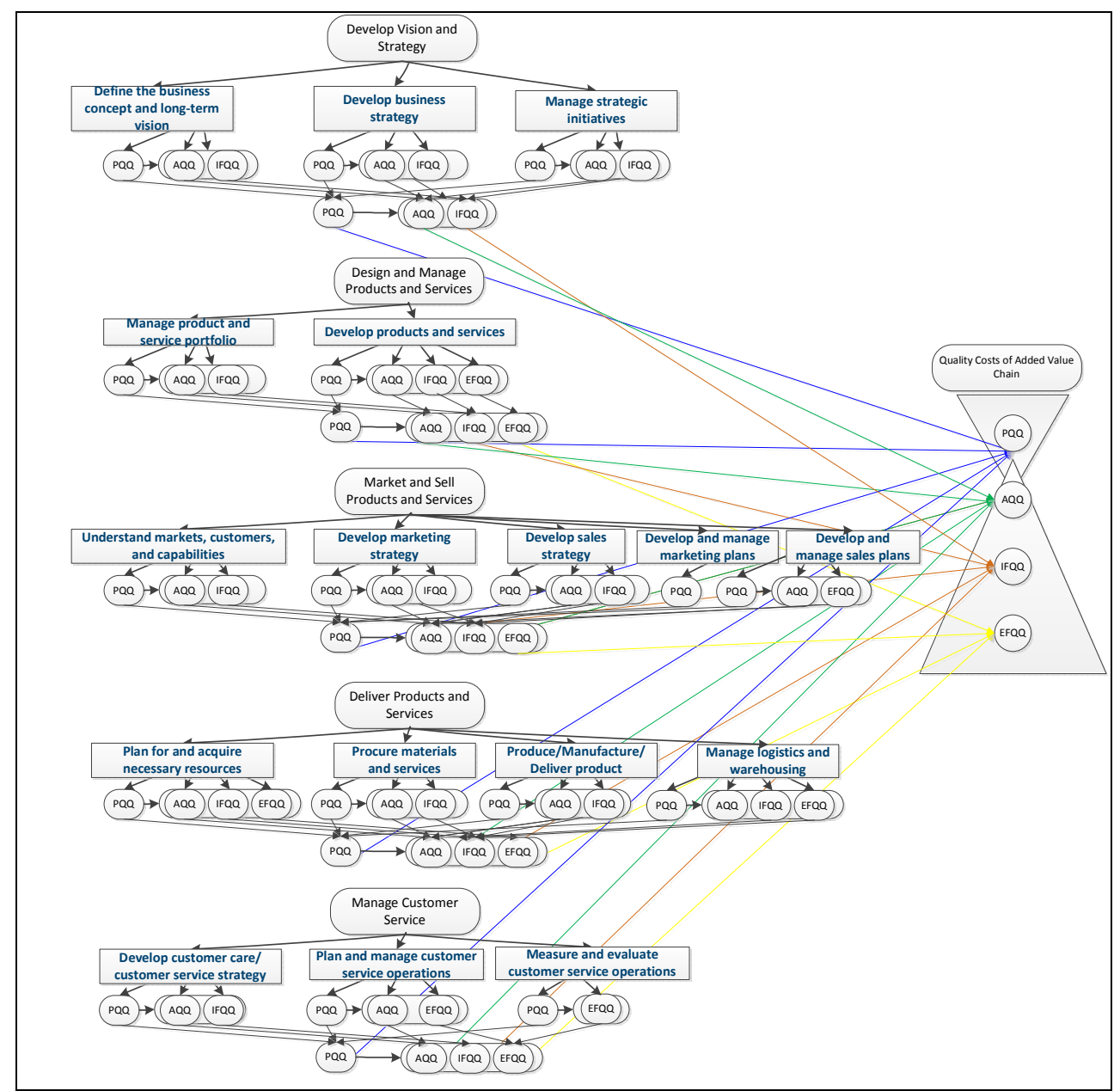

Figure 2 - The relationship between quality costs elements in each added value chain process, in each group of value added chain process and in all added value chain

A detail list of quality costs is presented in Appendix.

Third step: the formation of research framework of quality costs assessment in the aspect of the value added chain. By the third step, according to nomothetic point of view and inductive method and the second direction of Multiple Criteria Decision Analysis (i.e. Distinguish of quality costs elements for process quality assessment and continuous improvement decisions) was performed research framework of quality costs assessment in aspect of the value added chain. 


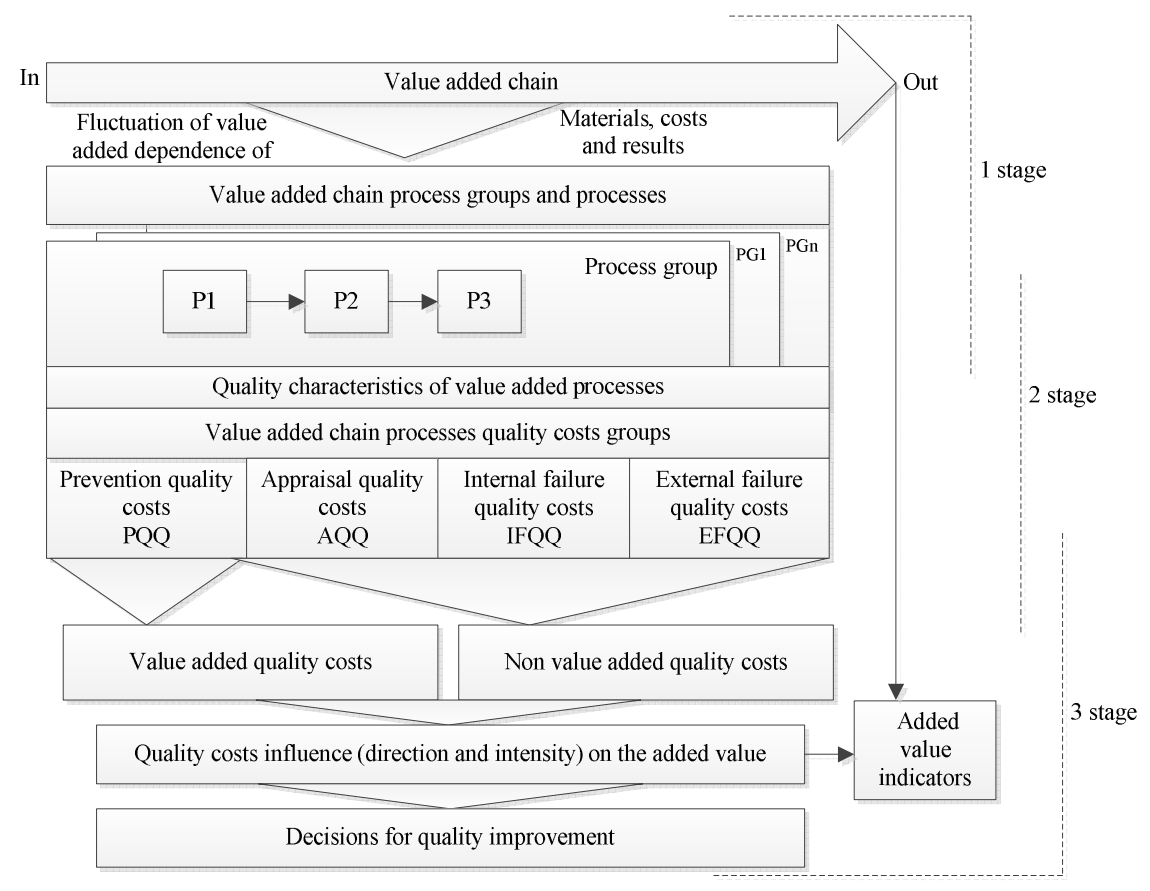

Figure 3 - Research framework of quality costs assessment in the aspect of added value chain

Research framework of quality costs assessment in the aspect of added value chain was composed of exogenous variables - prevention quality cost, appraisal quality costs, internal and external failure quality costs and endogenous variables - added value indicators (e.g. productivity, operational efficiency, customer satisfaction, etc.). During modelling stage was taken into account the economic meaningfulness, econometric bias and validity.

Research framework provides clear steps to follow quality costs assessment in aspect of the added value chain.

The first stage of quality costs assessment research framework in the aspect of added value chain consists of identification of added value chain and its process groups and processes. Moreover, in this stage organizations have to define indices reflecting added value alteration.

The second stage is seen as quality costs in the aspect of added value chain identification stage. Because of this, the research framework is used to calculated quality costs that are divided into the quality costs that create added value and the quality costs that do not create added value.

The quality costs genesis showed that quality costs in scientific studies are mostly divided into groups of conformity and nonconformity quality costs that are divided into groups of categories of preventive, appraisal, internal failure and external failure quality costs (Castillo-Vilar, Smith and Simonton, 2012; 
Rambudhin, Alzaman and Bulgak, 2008; et al.). Scientific research confirmed that there exists a negative relation between groups of preventive and appraisal as well as internal and external failure quality costs, i.e. increasing preventive and assessment quality costs decreases internal and external failure quality costs. However, it was determined that many scientists neglect accumulative effect of prevention quality costs to appraisal, internal failure and external failure quality costs. Therefore, during expert assessment were confirmed theoretical insights of Lorente, Rodriguez and Rawlins (1998). As a result, prevention quality costs were ascribed to the group of quality costs that create added value (value added quality costs), and appraisal, internal failure and external failure quality costs were ascribed to the group of quality costs that do not create added value (nonvalue added quality costs).

Based on the multi-criteria decision making principles, in order to confirm relations between calculated value added quality costs and non-value added quality costs are calculated correlation coefficients. Mathematically quality costs are calculated as follows:

$$
\begin{aligned}
& k(V A Q Q)=a_{V A Q Q}+b_{V A Q Q} k(t) \\
& b_{V A Q Q}=\frac{\sum_{i=1}^{n} k\left(t_{i}\right) k(V A Q Q)-n(n+1)^{2} / 4}{\sum_{i=1}^{n}\left[\left(t_{i V A Q Q}\right)\right]^{2}-n(n+1)^{2} / 4} \\
& a_{V A Q Q}=\left(1-b_{V A Q Q}\right)(n+1) \\
& k(N V A Q Q)=a_{N V A Q Q}+b_{N V A Q Q} k(t) \\
& b_{N V A Q Q}=\frac{\sum_{i=1}^{n} k\left(t_{i}\right) k(N V A Q Q)-n(n+1)^{2} / 4}{\sum_{i=1}^{n}\left[\left(t_{i N V A Q Q}\right)\right]^{2}-n(n+1)^{2} / 4} \\
& a_{N V A Q Q}=\left(1-b_{N V A Q Q}\right)(n+1) / 3
\end{aligned}
$$

Where:

$V A Q Q$ - value added quality costs;

$N V A Q Q$ - non value added quality costs;

$t$ - period of time;

$k(V A Q Q)-\mathrm{i}$, VAQQ value in increasing t curve;

$k\left(t_{i V A Q Q}\right)-\mathrm{i}, \mathrm{t}$ value in increasing $\mathrm{t}$ curve;

$k(N V A Q Q)-\mathrm{i}, \mathrm{NVAQQ}$ value in decreasing $\mathrm{t}$ curve;

$k\left(t_{\text {iNVAQQ }}\right)-\mathrm{i}, \mathrm{t}$ value in decreasing $\mathrm{t}$ curve;

$n$ - number of recorded data.

All quality costs are calculated as a sum of value added quality costs and nonvalue added quality costs:

$$
T Q Q=\sum_{i=n} k(V A Q Q)+k(N V A Q Q)
$$

Where:

$T Q Q$ - total quality costs. 
In striving to determine relations between value added quality costs and nonvalue added quality costs, in the third stage, a multiple linear regression analysis is performed. According to Cekanavicius and Murauskas (2014) regression analysis allows to forecast values of endogenic variable according to values of exogenous variables. Relations between value added and non-value added groups of quality costs $(V A Q Q \& N V A Q Q)$ are considered statistically important when significance level of the test is not bigger than 5 percent $(p<0,05)$. In striving to determine suitability of multipartite linear regression method, there is calculated a coefficient of determination $\left(R^{2}\right)$. With the reference to the sample size and number of independent variables, in case of multiple linear regression there can be used an adjusted coefficient of determination $\left(R^{2 a d j}\right)$. Adjusted coefficient of determination shows part of dispersion of endogenous (added value) variable that could be explained by exogenous variables (quality costs).

In this stage the influence of quality costs to added value is also calculated. For that purpose, Setijono and Dahlgaard (2008) two-dimentional vector of influence is also calculated. First part of vector's equation $\left(\frac{\mathrm{VA}_{t}}{\mathrm{VAQQ}_{\mathrm{t}}}\right)$ shows the influence of value added quality costs to added value $\left(V A_{t}\right)$, the second part of vector's equation $\left(\frac{\mathrm{NVAQQ}_{\mathrm{t}}}{\mathrm{VAQQ}_{\mathrm{t}}}\right)$ reflects the influence of value added quality costs to nonvalue added quality costs. With a reference of presumption changing value added quality costs influence vector change. Since dependence between variables is expressed by relative size, in order to denominate analysed data, two-dimensional influence vector $\bar{v}$ was transformed into scalar equation (7).

$$
\bar{v}=\sqrt{\left(\frac{V A_{t}}{V A Q Q_{t}}\right)^{2}+\left(\frac{N V A Q Q_{t}}{V A Q Q_{t}}\right)^{2}}
$$

Two-dimensional influence vector's value is equal to $\sqrt{2}=1.41$. If calculated twodimensional influence vector exceeds an estimated value, it shows that organization's investments to quality improvement activities were not sufficient and it has a negative impact on added value. Two-dimensional influence vector allows showing new bounds for the generalization of quality costs impact on added value.

\section{PILOT STUDY RESULTS}

The instrument to test the relations between value added quality costs and nonvalue added costs was a case study. The research was carried out during the period of a whole year from 2012 January till 2013 January in the textile manufacturing company. A quality costs analysis draft was based on the elements of quality costs in the aspect of added value chain (see Appendix) which were confirmed by the experts. Data were collected through in-depth financial, statistical and accounting data analysis and in-person interviews. 
The non-value added quality costs in comparison with total amount of quality costs were divided in the groups of the value added chain processes as follows:

In the group of vision and strategy development processes (define the business concept and long-term vision; develop business strategy; and manage strategic initiatives) the non-value added quality costs present a small part (5\%) of total quality costs amount. The non-value added quality costs of the products development and management processes group (manage product and service portfolio; develop products and services) were equal to $18 \%$ of total quality costs amount. The non-value added quality costs of the products sale development processes groups (understand markets, customers, and capabilities; develop marketing and sales strategy; develop and manage marketing plans; develop and manage sales plans) were equal to $13 \%$ total quality costs amount. The non-value added quality costs of the group of products manufacturing and presentation (plan for and acquire necessary resources (Supply Chain Planning); procure materials and services; produce/manufacture/deliver product; deliver service to customer; manage logistics and warehousing) were equal to $36 \%$ of total quality costs amount. The non-value added quality costs of the group of customers' service management (develop customer care/customer service strategy; plan and manage customer service operations; measure and evaluate customer service operations) were equal to $28 \%$ of total quality costs amount. All non-value added quality costs of the whole value chain were equal to $45 \%$ of total quality costs amount.

Therefore, in order to check the logic of the effect of the value added chain's processes quality costs effect on the value added assessment model, the total amount of all value chain's value added quality costs and non-value added quality costs were analysed and each month's two-dimensional influence vector was calculated. The costs of defective products were chosen to represent added value $(V A)$ indicator.

The obtained results reveal that during the periods where the value added quality costs exceed the non-value added quality costs, the calculated two-dimensional influence vector did not exceed nominal value $(1,41)$. It means that the increased value added quality costs influence both the decrease of non-value added quality costs and the decrease the costs of defective products. Such results indicate that observation of alternations of the two-dimensional influence vector, allows determining the tendency and intensity of value added cost to the non-value added costs as well as to the added value indicators.

\section{DISCUSSION AND CONCLUSION}

This study adds some insights into development quality costs theory. Especially, it builds an opportunity to analyse the effect of quality costs on the added value. The completed scientific research showed that there is no uniform definition of quality costs in scientific literature. Therefore, considering the definitions of 
quality costs proposed by scientists and the complexity of the added value the definition of quality costs was revealed. More specifically, it is significant impact on added value considering the 'enabling' role of quality.

Another important finding relates to proposed research framework which helps to better understand the assessment of quality costs, also to distinguish the relative importance to added value so that they can become potential sources for continuous improvement programs. The proposed research framework can contribute to the field of quality costs analysis in added value chain aspect in several ways. First, the research framework uses added value chain approach which is recognized as the dynamic system that generates the costs of interaction in the particular processes of added value chain. The research framework is based on the assumption that added value will be generated when the requirements and (or) specifications which were established by the consumers and (or) the organization will be synchronized with the processes. This will allow assuring determined level of quality through decreased non-conformance costs. Second, the assessment of quality costs in the aspect of value added chain is useful as quality costs complex assessment tool that is carried out observing the influence of the quality costs results on the value added. Considering this the assessment of quality costs from the perspective of hypothetical - deductive point of view is associated with the selection of quality costs classification method. On the basis of the expert evaluation results preventive quality costs are attributed to the group of the value added generating quality costs, whereas appraisal, internal failure and external failure quality costs are attributed to the group of the nonadded value generating quality costs. The meaning of these results is substantiated not by ordinary inductive summation of quality costs categories, whereas the deduction affirms that such expansion of the quality costs categories is recognized as the extension of Lorente, Rodriguez and Rawlins (1998) theoretical results. Third, this research framework could help to perform the measurement of the added value chain quality costs influence on the value added. Moreover, described vector that reflects the added value changes could help organizations to find right quality improvement actions.

The assessment of the elements of the added value chain quality costs, their grouping into the value added generating and the value added non-generating quality costs and the revelation of their effect "s trend and intensity on the value added are recognized as the biggest significance of the empirical study of this paper.

The results obtained provide valuable insights for the scientists of the business economic trends and the representatives of organizations, in order to understand the effect of quality costs on the added value. Organizations could use the list of the quality costs elements in the aspect of added value chain in order to assess the added value chain quality costs, also to compare the obtained results with the added value indicators, in order to determine quality improvement actions. 


\section{REFERENCES}

Abdelsalam, H.M. and Gad, M.M., 2009. Cost of quality in Dubai: An analytical case study of residential construction projects. International journal of project management, 27(5), pp.501-511.

Akkoyun, O. and Ankara, H., 2009. Cost of quality management: an empirical study from Turkish marble industry. Academic Journals. Scientific Research and Essay, 4(11), pp.1275-1285.

APQC, 2012. PCF - Process Classification Framework - APQC. USA. [online] Avialable at http://www.apqc.org/process-classification-framework [accesses 12 June, 2012].

Atkinson, R., 1999. Project management: cost, time and quality, two best guesses and a phenomenon, its time to accept other success criteria. International journal of project management, 17(6), pp.337-342.

Australian standart, 2012. AS 2561-1982 Guide to the determination and use of quality costs. Standards Australia: AS.

Bamford, D.R. and Land, N., 2006. The application and use of the PAF quality costing model within a footwear company. International Journal of Quality \& Reliability Management, 23(3), pp.265-278.

Barnes, S.J., 2002. The mobile commerce value chain: analysis and future developments. International Journal of Information Management, 22(2), pp.91108.

Buthmann, A., 2007. Cost of Quality: Not Only Failure Costs - iSixSigma. [online] Available at: http://www.isixsigma.com/implementation/financialanalysis/cost-quality-not-only-failure-costs/ [Accessed 07 May, 2015].

Calegre, F.A. and Papa, J.R.C., 2007. An empirical study of a quality cost system implementation: case study in a Brazilian machine tools manufacturer. Cuadernos de estudios empresariales, 17, pp.55-73.

Campanella, J., 1999. Principles of Quality Costs: principles, implementation and use. 3rd ed. New Delhi: Prentice-Hall.

Castillo-Villar, K.K., Smith, N.R. and Simonton, J.L., 2012. A model for supply chain design considering the cost of quality. Applied Mathematical Modelling, 36(12), pp.5920-5935.

Cheah, S., Shahbudin, A.S.M. and Taib, F.M., 2011. Tracking hidden quality costs in a manufacturing company: an action research. International Journal of Quality \& Reliability Management, 28(4), pp.405-425.

Chopra, A. and Garg, D., 2011. Behavior patterns of quality cost categories. The TQM Journal, 23(5), pp.510-515.

Chopra, A. and Garg, D., 2012. Introducing models for implementing cost of quality system. The TQM Journal, 24(6), pp.498-504. 
Christopher, M., 2005. Logistics and supply chain management: creating valueadding networks. Chester: Pearson education.

Crosby, P.B., 1979a. Quality is free: The art of making quality certain, 94. New York: McGraw-Hill.

Crosby, P.B., 1979b. Quality is free: The art of making quality free. New York: McGraw-Hill.

Curkovic, S., Sroufe, R. and Landeros, R., 2008. Measuring TQEM returns from the application of quality frameworks. Business Strategy and the Environment, 17(2), pp.93-106.

Cekanavicius, V., Murauskas, G., 2014. Taikomoji regresiné analizé socialiniuose tyrimuose. Vilnius: Vilniaus universiteto leidykla.

Dale, B.G. and Plunkett, J.J., 1995. Quality Costing, 2nd ed. London: Chapman and Hall.

Dale, B.G. and Plunkett, J.J., 1999. Quality costing. Farnham: Gower Publishing, Ltd.

Dale, B.G. and Wan, G.M., 2002. Setting up a quality costing system: an evaluation of the key issues. Business Process Management Journal, 8(2), pp.104-116.

De, R.N., 2009. Quality costing: An efficient tool for quality improvement measurement. In: IEEE Industrial Engineering and Engineering Management, 16th International Conference on. Beijing, China, 21 - 23 October 2009.

Edward, M. and Sahadev, S., 2011. Role of switching costs in the service quality, perceived value, customer satisfaction and customer retention linkage. Asia Pacific Journal of Marketing and Logistics, 23(3), pp.327-345.

Eldridge, S., Balubaid, M. and Barber, K.D., 2006. Using a knowledge management approach to support quality costing. International Journal of Quality \& Reliability Management, 23(1), pp.81-101.

Emsley, D., 2008. Different interpretations of a "fixed" concept: Examining Juran's cost of quality from an actor-network perspective. Accounting, Auditing \& Accountability Journal, 21(3), pp.375-397.

Feigenbaum, A.V., 1951. Quality control. New York: McGraw-Hill.

Fons, L.A.S., 2012. Integration of quality cost and accounting practices. The TQM Journal, 24(4), pp.338-351.

Freeman, J.M., 2008. The case for quality costing simulation. The TQM Journal, 20(5), pp.476-487.

Giakatis, G., Enkawa, T. and Washitani, K., 2001. Hidden quality costs and the distinction between quality cost and quality loss. Total Quality Management, 12(2), pp.179-190. 
Goulden, C. and Rawlins, L., 1995. A hybrid model for process quality costing. International Journal of Quality \& Reliability Management, 12(8), pp.32-47.

Harington, H.J., 1987. Poor-quality cost. New York: M. Dekker.

Yang, C.C., 2008. Improving the definition and quantification of quality costs. Total Quality Management Journal, 19(3), pp.175-191.

Jaju, S., Mohanty, R.P. and Lakhe, R.R., 2009. Towards managing quality cost: A case study. Total Quality Management, 20(10), pp.1075-1094.

Juran, J.M. and Gryna, F.M., 1988. Quality Control Handbook. 4th ed. New York: McGraw-Hill.

Juran, J.M., 1951. Quality Control Handbook. 1st ed. New York: Mcgraw-Hill.

Juran, J.M. and Godfrey, A.B., 1998. Juran's Quality Control Handbook. 5th ed. New York: Mcgraw-Hill.

Kaner, C., 1996. Quality cost analysis: Benefits and risks. Software QA, 3(1), p.23.

Kaplinsky, R. and Morris, M., 2001. A handbook for value chain research, 113. Ottawa: IDRC.

Kaplinsky, R., 2000. Globalisation and unequalisation: What can be learned from value chain analysis? Journal of development studies, 37(2), pp.117-146.

Kaplinsky, R., 2004. Spreading the gains from globalization: What can be learned from value-chain analysis? Problems of Economic Transition, 47(2), pp.74-115.

Kiani, B., Shirouyehzad, H., Bafti, F.K. and Fouladgar, H., 2009. System dynamics approach to analysing the cost factors effects on cost of quality. International Journal of Quality \& Reliability Management, 26(7), pp.685-698.

Kim, S. and Nakhai, B., 2008. The dynamics of quality costs in continuous improvement. International Journal of Quality \& Reliability Management, 25(8), pp.842-859.

Krishnan, S.K., 2006. Increasing the visibility of hidden failure costs. Measuring business excellence, 10(4), pp.77-101.

Krishnan, S.K., Agus, A. and Husain, N., 2000. Cost of quality: the hidden costs. Total Quality Management, 11(4-6), pp.844-848.

Lesser, W., 1954. Cost of quality. Industrial Quality Control, 11(5), pp.11-14.

Lorente, A.R. M., Rodriguez, A.G. and Rawlins, L., 1998. The cumulative effect of prevention. International Journal of Operations \& Production Management, 18(8), pp.727-739. 
Luther, R. and Sartawi, I.I., 2011. Managerial practices of quality costing: an evidence-based framework. International Journal of Quality \& Reliability Management, 28(7), pp.758-772.

Machowski, F. and Dale, B.G., 1998. Quality costing: An examination of knowledge, attitudes, and perceptions. Quality Management Journal, 5(3), pp. 84-95.

Miguel, P.C. and Pontel, S., 2004. Assessing quality costs of external failures (warranty claims). International Journal of Quality \& Reliability Management, 21(3), pp.309-318.

Moen, R.M., 1998. New quality cost model used as a top management tool. The TQM Magazine, 10(5), pp.334-341.

Omachonu, V.K., Suthummanon, S. and Einspruch, N.G., 2004. The relationship between quality and quality cost for a manufacturing company. International Journal of Quality \& Reliability Management, 21(3), pp.277-290.

Porter, L.J. and Rayner, P., 1992. Quality costing for total quality management. International Journal of Production Economics, 27(1), pp.69-81.

Ramdeen, C., Santos, J., and Chatfield, H.K., 2007. Measuring the cost of quality in a hotel restaurant operation. International Journal of Contemporary Hospitality Management, 19(4), pp.286-295.

Ramudhin, A., Alzaman, C. and Bulgak, A.A., 2008. Incorporating the cost of quality in supply chain design. Journal of Quality in Maintenance Engineering, 14(1), pp.71-86.

Reed, R., Lemak, D.J. and Mero, N.P., 2000. Total quality management and sustainable competitive advantage. Journal of Quality Management, 5(1), pp.526.

Roden, S. and Dale, B. (2000). Understanding the language of quality costing. The TQM Magazine, 12(3), pp.179-185.

Rust, R.T., Moorman, C. and Dickson, P.R., 2002. Getting return on quality: revenue expansion, cost reduction, or both? The Journal of Marketing, 66(4), pp.7-24.

Setijono, D. and Dahlgaard, J.J., 2008. The value of quality improvements. International Journal of Quality \& Reliability Management, 25(3), pp.298-312.

Sharabi, M. and Davidow, M., 2010. Service quality implementation: problems and solutions. International Journal of Quality and Service Sciences, 2(2), pp.189-205.

Sörqvist, L., 1998. Poor quality costing. Ph.D. Royal Institute of Technology.

Sower, V.E., 2004. Estimating External Failure Costs: A Key Difficulty in COQ Systems. In: Quality Congress.ASQ's, Annual Quality Congress Proceedings, 58, pp.547-551. 
Sower, V.E., Quarles, R. and Broussard, E., 2007. Cost of quality usage and its relationship to quality system maturity. International Journal of Quality \& Reliability Management, 24(2), pp.121-140.

Srivastava, S.K., 2008. Towards estimating cost of quality in supply chains. Total Quality Management \& Business Excellence, 19(3), pp.193-208.

Tawfek, H.S., Mohammed, H.E.D.H. and Razek, M.E.A., 2012. Assessment of the expected cost of quality (COQ) in construction projects in Egypt using artificial neural network model. HBRC journal, 8(2), pp.132-143.

Tannock, J. and Saelem, S., 2007. Manufacturing disruption costs due to quality loss. International Journal of Quality \& Reliability Management, 24(3), pp.263278.

Tena, A.B.E., Llusar, J.C.B. and Puig, V.R., 2001. Measuring the relationship between total quality management and sustainable competitive advantage: A resource-based view. Total quality management, 12(7-8), pp.932-938.

Tye, L.H., Halim, H.A. and Ramayah, T., 2011. An exploratory study on cost of quality implementation in Malaysia: The case of Penang manufacturing firms. Total Quality Management \& Business Excellence, 22(12), pp.1299-1315.

Uyar, A., 2008. An exploratory study on quality costs in Turkish manufacturing companies. International Journal of Quality \& Reliability Management, 25(6), pp.604-620.

Weheba, G.S. and Elshennawy, A.K., 2004. A revised model for the cost of quality. International Journal of Quality \& Reliability Management, 21(3), pp.291-308.

Wood, D.C., 2013. Principles of Quality Costs: Financial Measures for Strategic Implementation of Quality Management. $4^{\text {th }}$ ed. U.S: American Society for Quality, Quality Press. 


\section{APPENDIX}

The elements of quality costs in the aspect of added value chain

\begin{tabular}{|c|c|c|}
\hline Process & Quality costs & $\begin{array}{c}\text { Category of quality } \\
\text { costs } \\
\text { PQQ, AQQ, IFQQ, } \\
\text { EFQQ }\end{array}$ \\
\hline \multirow{11}{*}{$\begin{array}{l}\text { Define the business concept } \\
\text { and long-term vision }\end{array}$} & Competitor assessment costs & PQQ \\
\hline & The economic situation analysis costs & PQQ \\
\hline & The legislative analysis costs & PQQ \\
\hline & New technologies accessibility evaluation costs & PQQ \\
\hline & Ecology legislation analysis costs & PQQ \\
\hline & Consumer requirements analysis costs & PQQ \\
\hline & Process design costs & PQQ \\
\hline & Stakeholder survey costs & PQQ \\
\hline & Organizations characteristics analysis costs & $\mathrm{AQQ}$ \\
\hline & Additional costs that occur because of errors in research and data analysis & IFQQ \\
\hline & Incorrectly identified processes cost centres & IFQQ \\
\hline \multirow{5}{*}{ Develop business strategy } & The definition costs of strategic objectives and indicators & PQQ \\
\hline & Responsibilities assignment costs & PQQ \\
\hline & Existing situation analysis costs & AQQ \\
\hline & Developed strategy evaluation costs & $\mathrm{AQQ}$ \\
\hline & $\begin{array}{l}\text { Costs incurred due to improper performance goals and objectives for defining } \\
\text { indicators }\end{array}$ & IFQQ \\
\hline \multirow{3}{*}{ Manage strategic initiatives } & Strategic directions development costs & PQQ \\
\hline & Strategic directions evaluation cost & $\mathrm{AQQ}$ \\
\hline & Costs incurred for re-established strategic directions & IFQQ \\
\hline \multirow{6}{*}{$\begin{array}{l}\text { Manage product and service } \\
\text { portfolio }\end{array}$} & Market research costs & PQQ \\
\hline & Customer surveys and analysis costs & PQQ \\
\hline & Responsible for product planning employees salary costs & PQQ \\
\hline & Additional costs that occur because of errors in planning product & IFQQ \\
\hline & Costs for bad understanding of customers' needs & IFQQ \\
\hline & $\begin{array}{l}\text { Cost (market, sales, ...) related with incorrect product planning (affecting the } \\
\text { subsequent processes, activities) }\end{array}$ & IFQQ \\
\hline \multirow{22}{*}{$\begin{array}{l}\text { Develop products and } \\
\text { services }\end{array}$} & In design activities involved employee training costs & PQQ \\
\hline & Product prototyping costs & PQQ \\
\hline & New product certification costs & PQQ \\
\hline & Production process improvement costs & PQQ \\
\hline & Pilot production and assembly work costs & AQQ \\
\hline & Product design review costs & AQQ \\
\hline & Transaction costs associated with the test product testing & AQQ \\
\hline & $\begin{array}{l}\text { The costs associated with repeated testing if it is needed to change product } \\
\text { design }\end{array}$ & AQQ \\
\hline & The production process quality control costs & AQQ \\
\hline & Production operations testing and inspection costs & AQQ \\
\hline & Costs related to the failed test products & IFQQ \\
\hline & $\begin{array}{l}\text { Personnel, equipment, raw materials and time costs associated with redesigning } \\
\text { the product }\end{array}$ & IFQQ \\
\hline & The product re-certification costs associated with the changing product project & IFQQ \\
\hline & $\begin{array}{l}\text { The costs incurred by changing raw materials purchased in connection with the } \\
\text { project change }\end{array}$ & IFQQ \\
\hline & $\begin{array}{l}\text { Increased costs for downtime and delays in getting products on the draft } \\
\text { amendment }\end{array}$ & IFQQ \\
\hline & Solving with the design process quality-related problems costs & IFQQ \\
\hline & $\begin{array}{l}\text { Additional working hours, equipment and material costs, if the problems arise } \\
\text { during production system verification process }\end{array}$ & IFQQ \\
\hline & $\begin{array}{l}\text { The costs associated with the process of re-certification of improper process } \\
\text { design }\end{array}$ & IFQQ \\
\hline & Costs related with increased production amount $\mathrm{s}$ in stock & IFQQ \\
\hline & $\begin{array}{l}\text { Compensation for customers who have suffered losses due to improper product } \\
\text { design }\end{array}$ & EFQQ \\
\hline & The costs for the customer complaints, associated with product design, solution & EFQQ \\
\hline & $\begin{array}{l}\text { The costs associated with returned products faults, caused by design errors and } \\
\text { disposal }\end{array}$ & EFQQ \\
\hline \multirow{2}{*}{$\begin{array}{l}\text { Understand markets, } \\
\text { customers, and capabilities }\end{array}$} & Customers and market assessment costs & PQQ \\
\hline & Market segments analysis costs & PQQ \\
\hline
\end{tabular}

ISSN 1335-1745 (print) ISSN 1338-984X (online) 
Quality InNovation Prosperity / KVAlita InOVÁcia Prosperita 20/2 - 2016141

\begin{tabular}{|c|c|c|}
\hline Process & Quality costs & $\begin{array}{c}\text { Category of quality } \\
\text { costs } \\
\text { PQQ, AQQ, IFQQ, } \\
\text { EFQQ }\end{array}$ \\
\hline & Internal and external business environment analysis costs & PQQ \\
\hline & The costs of competing products research & PQQ \\
\hline & $\begin{array}{l}\text { Costs related to the mislabelling market opportunities, market segments } \\
\text { identification }\end{array}$ & IFQQ \\
\hline & The costs that occur because of errors in research and data analysis & IFQQ \\
\hline \multirow{7}{*}{$\begin{array}{l}\text { Develop marketing and sales } \\
\text { strategy }\end{array}$} & Marketing strategies and evaluation indicators creation cost & PQQ \\
\hline & Marketing plans development costs & PQQ \\
\hline & Customer loyalty and value definition costs & PQQ \\
\hline & Costs associated with the incorrect naming of market segments & IFQQ \\
\hline & Costs associated with the wrong product brand positioning & IFQQ \\
\hline & Costs associated with the wrong product pricing & IFQQ \\
\hline & Costs associated with incorrect sales channels & IFQQ \\
\hline \multirow{11}{*}{$\begin{array}{l}\text { Develop and manage } \\
\text { marketing plans }\end{array}$} & Sales forecasting costs & PQQ \\
\hline & Sales strategy development costs & PQQ \\
\hline & Determination of sales strategy and performance indicators costs & PQQ \\
\hline & Sales opportunity analysis costs & AQQ \\
\hline & Developed sales strategy evaluation costs & $\mathrm{AQQ}$ \\
\hline & $\begin{array}{l}\text { Costs incurred due to improper setting of sales objectives and performance } \\
\text { indicators }\end{array}$ & IFQQ \\
\hline & $\begin{array}{l}\text { Cost related with incorrect defined value for the product for different market } \\
\text { segments }\end{array}$ & IFQQ \\
\hline & Sales budget conversion costs & IFQQ \\
\hline & Losses associated with the wrong set of designed product variable costs & IFQQ \\
\hline & Losses associated with the wrong specified product projected regular costs & IFQQ \\
\hline & Losses associated with incorrectly calculated the projected sales revenue & IFQQ \\
\hline \multirow{5}{*}{$\begin{array}{l}\text { Develop and manage sales } \\
\text { plans }\end{array}$} & Sales plans for development costs & PQQ \\
\hline & Sales plans for assessment costs & $\mathrm{AQQ}$ \\
\hline & Sales plans correction costs & IFQQ \\
\hline & Loss of missed sales channels & IFQQ \\
\hline & Costs associated with incorrect information about customers & IFQQ \\
\hline \multirow{20}{*}{$\begin{array}{c}\text { Plan for and acquire } \\
\text { necessary resources } \\
\text { (Supply Chain Planning), } \\
\text { Procure materials and } \\
\text { services }\end{array}$} & Raw material supply planning costs & PQQ \\
\hline & Raw material supplier evaluation costs & PQQ \\
\hline & Costs related to the suppliers' certification & PQQ \\
\hline & Investments in the raw materials testing equipment & PQQ \\
\hline & Reward employees for the raw materials inspection and testing & PQQ \\
\hline & Raw material certification costs & PQQ \\
\hline & Raw material inspection costs & AQQ \\
\hline & $\begin{array}{l}\text { Costs incurred due to procurement of raw materials evaluation and testing } \\
\text { equipment maintenance and calibration }\end{array}$ & AQQ \\
\hline & $\begin{array}{l}\text { Cost of downtime, additional inventory costs, solving quality problems costs } \\
\text { due to bad quality raw materials }\end{array}$ & IFQQ \\
\hline & $\begin{array}{l}\text { Raw materials purchased replacement cost, which appeared incorrectly } \\
\text { assessed supplier }\end{array}$ & IFQQ \\
\hline & The costs of raw materials due to product supply delay & IFQQ \\
\hline & Costs incurred of elimination of purchased raw materials & IFQQ \\
\hline & Costs incurred by replacing raw materials & IFQQ \\
\hline & $\begin{array}{l}\text { losts incurred in solving problems related to the quality of purchased raw } \\
\text { materials }\end{array}$ & IFQQ \\
\hline & $\begin{array}{l}\text { The costs incurred by processing products manufactured by acquiring new } \\
\text { materials and additional inventory, related with a poor quality of purchased raw } \\
\text { materials }\end{array}$ & IFQQ \\
\hline & Additional labour costs reprocess poor quality raw materials & IFQQ \\
\hline & $\begin{array}{l}\text { Additional costs when poor quality materials are bought and it is an urgent } \\
\text { need to buy another material }\end{array}$ & IFQQ \\
\hline & $\begin{array}{l}\text { Cost of downtime, as well as the purchase of additional inventory due to poor } \\
\text { quality raw materials }\end{array}$ & IFQQ \\
\hline & $\begin{array}{l}\text { Returned products storage costs, as they were processed by using poor-quality } \\
\text { raw materials }\end{array}$ & EFQQ \\
\hline & $\begin{array}{l}\text { Costs associated with rework of returned products, because of the poor quality } \\
\text { raw materials }\end{array}$ & EFQQ \\
\hline \multirow{5}{*}{$\begin{array}{l}\text { Produce/Manufacture/Deliver } \\
\text { product }\end{array}$} & Operations quality planning costs & PQQ \\
\hline & Quality assessment and control equipment design and development costs & PQQ \\
\hline & Responsible for quality training costs & PQQ \\
\hline & Quality Department personnel costs & $\mathrm{PQQ}$ \\
\hline & Quality training costs & PQQ \\
\hline
\end{tabular}

ISSN 1335-1745 (print) ISSN 1338-984X (online) 


\begin{tabular}{|c|c|c|}
\hline Process & Quality costs & $\begin{array}{c}\text { Category of quality } \\
\text { costs } \\
\text { PQQ, AQQ, IFQQ, } \\
\text { EFQQ }\end{array}$ \\
\hline & Quality improvement costs & PQQ \\
\hline & $\begin{array}{l}\text { Costs for the purchase of quality control measurement instruments and } \\
\text { equipment }\end{array}$ & PQQ \\
\hline & Inspection and testing instruments acquisition and maintenance costs & PQQ \\
\hline & Inspection and testing costs & PQQ \\
\hline & Production operations restructuration costs & PQQ \\
\hline & Production operations improvement costs & PQQ \\
\hline & Product quality planning costs & PQQ \\
\hline & $\begin{array}{l}\text { Product quality assessment, control and inspection equipment design and } \\
\text { development costs }\end{array}$ & PQQ \\
\hline & Testing or validation of equipment acquisition and maintenance costs & PQQ \\
\hline & Manufacturing process validation costs & $\mathrm{AQQ}$ \\
\hline & Quality system audit costs & $\mathrm{AQQ}$ \\
\hline & Scheduled operations inspection, testing and audit costs & $\mathrm{AQQ}$ \\
\hline & Product quality assessment costs & $\mathrm{AQQ}$ \\
\hline & Process quality assessment costs & $\mathrm{AQQ}$ \\
\hline & Maintenance and calibration costs & $\mathrm{AQQ}$ \\
\hline & Testing and inspection data revision costs & $\mathrm{AQQ}$ \\
\hline & Process review preparation and analysis costs & AQQ \\
\hline & Acting process interference detection and fault analysis costs & AQQ \\
\hline & Product quality assessment costs & AQQ \\
\hline & Product inspection and functional test equipment maintenance costs & $\mathrm{AQQ}$ \\
\hline & Costs associated with product quality control work & AQQ \\
\hline & Costs associated with the maintenance and calibration work & AQQ \\
\hline & Product correction actions costs & IFQQ \\
\hline & Proceed correction actions costs & IFQQ \\
\hline & The costs incurred in taking operation correction actions & IFQQ \\
\hline & Re-process / operation inspection / testing costs & IFQQ \\
\hline & $\begin{array}{l}\text { The costs, when you need to pay for additional working hours, managing non- } \\
\text { conformance product that was identified during the process }\end{array}$ & IFQQ \\
\hline & $\begin{array}{l}\text { Costs of raw materials and equipment needed for the improving process, } \\
\text { resulting non-conformance product }\end{array}$ & IFQQ \\
\hline & $\begin{array}{l}\text { Costs of additional worked hours and used raw materials, which arose due to } \\
\text { improper destruction of controlled process produced non-conformance product }\end{array}$ & IFQQ \\
\hline & $\begin{array}{l}\text { Cost of downtime, as well as the purchase costs of additional inventory in order } \\
\text { to improve the process }\end{array}$ & IFQQ \\
\hline & Costs that arose to eliminate deficiencies in the quality control system & IFQQ \\
\hline & Costs incurred due to the of non-compliant quality orders & IFQQ \\
\hline & Costs resulting from a delay in time to comply with the order & IFQQ \\
\hline & Costs for the removal of defects after finished product inspection & IFQQ \\
\hline & Troubleshooting or improper process analysis (cost when a product is made) & IFQQ \\
\hline & Non-conformance product costs & IFQQ \\
\hline & Manufactured products re-process or repair costs & IFQQ \\
\hline & Re-inspection / testing costs & IFQQ \\
\hline & $\begin{array}{l}\text { Costs for additional working hours of the accumulation non-conformance } \\
\text { products }\end{array}$ & IFQQ \\
\hline & $\begin{array}{l}\text { Costs of materials needed for the re-processing accumulated non-conformance } \\
\text { products }\end{array}$ & IFQQ \\
\hline & $\begin{array}{l}\text { Costs arising from the treatment and repair of returned products that have been } \\
\text { properly checked after production }\end{array}$ & IFQQ \\
\hline & $\begin{array}{l}\text { Costs related with rising returned non-conformance products in stock, which } \\
\text { was not properly checked after production }\end{array}$ & IFQQ \\
\hline & $\begin{array}{l}\text { Costs arising from the delay deliver product to the market, which is due to } \\
\text { poorly carried out final inspection }\end{array}$ & IFQQ \\
\hline & $\begin{array}{l}\text { Additional costs due to improper final product inspection and testing (e.g. .: } \\
\text { fine) }\end{array}$ & IFQQ \\
\hline & Ecology legislation noncompliance fine & IFQQ \\
\hline \multirow{7}{*}{ Deliver service to customer } & Specific manufacturing requirements for individual customer design costs & PQQ \\
\hline & Individual customer manufacturing services planning costs & PQQ \\
\hline & Individual production of raw materials distribution plan deliver costs & PQQ \\
\hline & Costs of customers feedback survey on the provided service & PQQ \\
\hline & Manufacturing services quality assurance costs & $\mathrm{AQQ}$ \\
\hline & Losses associated with individual service planning & IFQQ \\
\hline & Losses associated with incorrectly prepared materials distribution plan & IFQQ \\
\hline
\end{tabular}


Quality Innovation Prosperity / Kvalita Inovácia Prosperita 20/2 - 2016143

\begin{tabular}{|c|c|c|}
\hline Process & Quality costs & $\begin{array}{l}\text { Category of quality } \\
\text { costs } \\
\text { PQQ, AQQ, IFQQ, } \\
\text { EFQQ }\end{array}$ \\
\hline & Non-conformance production service costs & IFQQ \\
\hline & Production services non-conformance identification costs & IFQQ \\
\hline \multirow{14}{*}{$\begin{array}{l}\text { Manage logistics and } \\
\text { warehousing }\end{array}$} & $\begin{array}{l}\text { Responsible for sales /logistics staff training costs, conveying knowledge about } \\
\text { the product }\end{array}$ & PQQ \\
\hline & Operating instructions for users delivering costs & PQQ \\
\hline & Protective product packaging costs & PQQ \\
\hline & $\begin{array}{l}\text { Special equipment for the transportation of the product acquisition and } \\
\text { maintenance costs }\end{array}$ & PQQ \\
\hline & Cargo insurance costs & PQQ \\
\hline & Product inventory and spare parts analysis cost & AQQ \\
\hline & Costs associated with the wrong transportation schedule preparation & IFQQ \\
\hline & Repeated delivery costs for the during delivery upraised errors & IFQQ \\
\hline & Costs incurred as a result of pricing uncertainty or error & IFQQ \\
\hline & Costs associated with returned products storage & IFQQ \\
\hline & Transportation costs of returned products & EFQQ \\
\hline & The costs associated with defective orders & EFQQ \\
\hline & Costs incurred due to incorrect product delivery & EFQQ \\
\hline & Costs incurred by replacing the product or spare part & EFQQ \\
\hline \multirow{6}{*}{$\begin{array}{c}\text { Develop customer } \\
\text { care/customer service } \\
\text { strategy }\end{array}$} & Consumer service strategy design costs & PQQ \\
\hline & Costs related to the analysis of existing customers & PQQ \\
\hline & Provided after sell service quality level identification costs & PQQ \\
\hline & Costs related to consumer feedback data analysis & AQQ \\
\hline & Costs associated with the wrong set of consumer segments & IFQQ \\
\hline & Costs associated with the incorrectly identified after sell services & IFQQ \\
\hline \multirow{16}{*}{$\begin{array}{l}\text { Plan and manage customer } \\
\text { service operations }\end{array}$} & Supporting service quality cost & PQQ \\
\hline & Customer service improvement costs & PQQ \\
\hline & Customer service centre costs & AQQ \\
\hline & Costs incurred due to inadequate communication with the customer & EFQQ \\
\hline & Costs related to customer dissatisfaction & EFQQ \\
\hline & $\begin{array}{l}\text { Compensation to consumers for delivered non-conformance product or (and) } \\
\text { provided non-conformance after sell services }\end{array}$ & EFQQ \\
\hline & Orders related with after-sales services faults cancellation costs & EFQQ \\
\hline & $\begin{array}{l}\text { Extra working hours and additional materials costs related with non- } \\
\text { conformance after sell service }\end{array}$ & EFQQ \\
\hline & Customer loyalty loss costs & EFQQ \\
\hline & Cost of the loss of the organization's image & EFQQ \\
\hline & Costs of loss of market share & EFQQ \\
\hline & Costs related to the product label loss & EFQQ \\
\hline & $\begin{array}{l}\text { Costs that occur in the processing and repairing returned non-conformance } \\
\text { product }\end{array}$ & EFQQ \\
\hline & Warranty claims costs & EFQQ \\
\hline & Warranty repair costs & EFQQ \\
\hline & $\begin{array}{l}\text { Fines paid for customers related with damage/injury caused by non- } \\
\text { conformance products }\end{array}$ & EFQQ \\
\hline \multirow{3}{*}{$\begin{array}{l}\text { Measure and evaluate } \\
\text { customer service operations }\end{array}$} & Customer satisfaction survey costs & PQQ \\
\hline & Costs associated with identification of quality improvement decisions & PQQ \\
\hline & Consumer complaints analysis and decision-making costs & EFQQ \\
\hline
\end{tabular}




\section{ABOUT THE AUTHORS}

Dr. Asta Daunorienė currently employed as senior lecturer by the School of Economics and Business at Kaunas University of Technology. As a freelance consultant Asta's professional expertise relates with quality management and value chain design. Asta gained her doctor of philosophy in Social Sciences (Economics). Asta's research interests explore quality (especially quality costs) and process management, sustainable university and business models, and value chain management areas.

Prof., dr. Eglè Staniskiene is a professor at the Department of Management, School of Economics and Business, Kaunas University of Technology. Her research interests are sustainable university, sustainable development, quality management systems, higher education quality research, education policy research methodology and interdisciplinary research. She is an author of more than 40 publications. 